\title{
Jenis Fitoplankton di Perairan Sekitar PLTU Tambak Lorok Semarang
}

\author{
Clarence Daffa Ananta*, Ria Azizah Tri Nuraini, Ibnu Pratikto \\ Departemen IImu Kelautan, Fakultas Perikanan dan IImu Kelautan, Universitas Diponegoro \\ Jl. Prof.H.Soedarto S.H, Tembalang,Semarang, Jawa Tengah 50275 Indonesia \\ ${ }^{*}$ Corresponding author, e-mail : anantadaffaa@gmail.com
}

\begin{abstract}
ABSTRAK: Salah satu pemanfaatan lingkungan pesisir dan laut adalah pembangunan Pembangkit Listrik Tenaga Uap (PLTU), karena sistem penyediaan air yang dibutuhkan untuk operasional PLTU berasal dari air laut. Kenaikan suhu permukaan laut akibat adanya aktivitas PLTU akan mempengaruhi organisme pada perairan tersebut, salah satunya adalah fitoplankton. Fitoplankton merupakan organisme autotroph yang mengandung pigmen klorofil sehingga dapat melakukan proses fotosintesis dengan memanfaatkan cahaya matahari. Tujuan penelitian ini adalah untuk mengkaji komposisi dan kelimpahan fitoplankton di perairan sekitar PLTU Tambak Lorok Semarang. Metode yang digunakan dalam penelitian ini adalah metode deskriptif eksploratif, sedangkan dalam pengambilan sampel penelitian, digunakan metode purposive sampling. Hasil kelimpahan fitoplankton secara keseluruhan di Perairan Tambak Lorok, yang tertinggi terdapat pada stasiun 3 dengan jumlah sebesar 4035,7 Ind/L sedangkan pada stasiun 2 dengan jumlah sebesar 2812,7 Ind/L dan kelimpahan terendah terdapat pada stasiun 1 dengan jumlah sebesar $1494,7 \mathrm{Ind} / \mathrm{L}$. Terjadi kenaikan suhu sebesar $5^{\circ} \mathrm{C}$ dengan nilai suhu mencapai $36,2^{\circ} \mathrm{C}$ pada stasiun 1 yang memiliki jarak $300 \mathrm{~m}$ dari titik outfall, suhu kemudian mengalami penurunan sebesar $3^{\circ} \mathrm{C}$ dengan nilai suhu sebesar $33,7^{\circ} \mathrm{C}$ pada stasiun 2 , dan terjadi penurunan pada stasiun 3 hingga nilai suhu sebesar $32,8^{\circ} \mathrm{C}$ dimana suhu sudah mendekati nilai normal suhu perairan sebesar $31^{\circ} \mathrm{C}$. Dapat disimpulkan bahwa nilai kelimpahan fitoplankton mengalami penurunan seiring dengan meningkatnya kenaikan suhu permukaan laut pada Perairan Tambak Lorok Semarang.
\end{abstract}

Kata kunci: PLTU; Kenaikan Suhu Permukaan Laut; Fitoplankton

\section{The Abundance of Phytoplankton in Waters Around Electric Steam Power Plant Tambak Lorok Semarang}

ABSTRACT: One of the utilization of coastal and ocean environment is the development of electric steam power plant since the water required for the operational comes from seawater. The disposal location of the used seawater is in the form of waste heat, streamed into the ocean; therefore it caused the rise of sea-level temperature. The rising sea level temperature will affect the organism on those waters; one of them is phytoplankton. Phytoplankton is an autotroph organism that contains chlorophyll pigment so it can do photosynthesis process using the sunlight. This research aims to study the abundance of phytoplankton in waters around electric steam power plant Tambak Lorok Semarang. The method used in this research is the explorative, descriptive method, while the sampling method is purposive sampling. The highest phytoplankton abudance in Tambak Lorok Waters is located on the third station with 4035,7 Ind/L, while on the second station is $2812,7 \mathrm{Ind} / \mathrm{L}$ and the lowest abundance is on the first station with only 1494,7 Ind/L. The increase of sea-level temperature is up to $5^{\circ} \mathrm{C}$ with the temperature value reached $36,2^{\circ} \mathrm{C}$ on the first station that located $300 \mathrm{~m}$ from the power plant outfall. The temperature then drops $3^{\circ} \mathrm{C}$ with the value of $33,7^{\circ} \mathrm{C}$ on the second station. The temperature then drops on the third station with the value of $32,8^{\circ} \mathrm{C}$ where it's closed to average sea level temperature, which is $31^{\circ} \mathrm{C}$. It can be concluded that the abundance of phytoplankton decreased along with the increase of sea level temperature in Tambak Lorok Waters.

Keywords: Electric Steam Power Plant; Sea Level Temperature Rise; Phytoplankton 


\section{PENDAHULUAN}

Pembangunan PLTU di wilayah pesisir dikarenakan sistem penyediaan air yang dibutuhkan untuk operasional PLTU dalam menggerakan turbin dan sistem pendingin menggunakan air yang berasal dari laut. Permasalahan utama kegiatan PLTU ini adalah suhu air buangan dari sistem pendingin yang jauh lebih tinggi dari suhu perairan di sekitarnya. Umumnya suhu air buangan tersebut dapat mencapai $40^{\circ} \mathrm{C}$. Sementara suhu perairan di sekitarnya hanya sekitar $30^{\circ} \mathrm{C}$ (Wibowo dan Asvaliantina, 2018). PLTU yang berada di wilayah pesisir Semarang adalah PT. Indonesia Power, dimana dalam kegiatan operasionalnya dibutuhkan air laut sebanyak kurang lebih 521.000 $\mathrm{m} 3 /$ hari. Lokasi pembuangan air laut yang telah berupa limbah air panas yang dialirkan langsung menuju perairan Tambak Lorok Semarang, dengan masuknya limbah air bahang ke perairan tersebut diduga akan mengakibatkan kenaikan suhu permukaan laut (Wijaya et al., 2015). Menurut Nontji (1987), suhu permukaan laut di Indonesia umumnya berkisar antara $28^{\circ} \mathrm{C}-31^{\circ} \mathrm{C}$, namun pada perairan yang merupakan wilayah pembuangan limbah industry atau pembangkit listik dapat mengalami kenaikan suhu sebesar $6^{\circ} \mathrm{C}$ sehingga suhu perairannya mencapai $37^{\circ} \mathrm{C}$. Masuknya limbah panas ke perairan akan merubah ambien suhu permukaan laut dan dapat mempengaruhi ekosistem akuatik baik secara langsung maupun tidak langsung (Subardjo dan Ario, 2015). Lebih lanjut menurut Sitinjak et al (2017), pembuangan limbah panas atau air bahang ke perairan laut tanpa adanya proses pendinginan akan berdampak pada meningkatnya suhu permukaan air laut.

Salah satu organisme yang terpengaruh dengan naiknya suhu permukaan laut adalah fitoplankton. Fitoplankton merupakan organisme autotroph yang mengandung pigmen klorofil sehingga dapat melakukan proses fotosintesis dengan memanfaatkan cahaya matahari. Sebagai organisme autotrof, fitoplankton adalah produsen dalam rantai makanan yang memproduksi bahan organik dari bahan anorganik (Aryawati dan Thoha, 2011). Menurut Arisyana dan Yuliana (2012), dengan terjadinya kenaikan suhu permukaan laut dapat mempengaruhi nilai kelimpahan dari fitoplankton pada perairan tersebut. Menurut Effendi (2003), nilai kisaran suhu yang optimum untuk pertumbuhan fitoplankton berkisar antara $20^{\circ} \mathrm{C}-30^{\circ} \mathrm{C}$, jika terjadi kenaikan suhu sebesar $10^{\circ} \mathrm{C}$ pada suatu perairan, maka konsumsi oksigen oleh organisme perairan tersebut termasuk fitoplankton akan meningkat sebanyak $2-3$ kali lipat dari biasanya karena tiap organisme perairan memiliki kecepatan metabolik yang berbeda

Penelitian ini penting untuk dilakukan untuk mengkaji dampak dari pembuangan limbah air panas, karena kenaikan suhu permukaan laut dapat menyebabkan rendahnya kelimpahan fitoplankton pada suatu perairan, hal ini dapat terjadi karena kemampuan organisme laut tersebut untuk bertahan hidup sangat diragukan (Subardjo et al., 2016). Selain itu, kemampuan organisme laut tersebut untuk bertahan hidup sangat diragukan (Subardjo et al., 2016). Berdasarkan penelitian yang dilakukan oleh Wijaya et al (2015) mengenai studi variabilitas spasial dan temporal suhu permukaan laut ada perairan PLTU Sumuradem Indramayu, terjadi kenaikan suhu sebesar $36^{\circ} \mathrm{C}$ dan limbah air bahang tersebar hingga jarak 2,25 km kearah barat laut perairan Indramayu, sedangkan berdasarkan penelitian yang dilakukan oleh Indraswari et al (2015) mengenai struktur komunitas fitoplankton di perairan yang terdampak air bahang PLTU Paiton, terjadi kenaikan suhu permukaan laut sebesar $33,58^{\circ} \mathrm{C}$ dan rendahnya nilai kelimpahan fitoplankton di titik outfall. Kenaikan suhu permukaan laut dapat mempengaruhi kehidupan organisme perairan khususnya fitoplankton, Terjadinya peningkatan suhu permukaan laut dapat mempengaruhi nilai struktur komunitas fitoplankton yang meliputi komposisi dan kelimpahan (Yuliana et al.,2012), sehingga penelitian ini bertujuan untuk mengkaji bagaimana komposisi dan kelimpahan jenis fitoplankton di perairan sekitar PLTU Tambak Lorok Semarang.

\section{MATERI DAN METODE}

Materi dalam penelitian ini adalah sampel fitoplankton yang diambil di perairan Tambak Lorok Semarang dan suhu permukaan laut yang diperoleh dari pengukuran langsung di lapangan dan digunakan untuk verifikasi data suhu hasil analisa citra satelit Landsat - 8. Penggunaan citra pada penelitian ini bertujuan untuk mengetahui sebaran air bahang PT. Indonesia Power dengan cara mengkaji nilai kenaikan suhu permukaan laut yang dihasilkan citra dengan Path/Row : 120/65. Citra tersebut diolah menggunakan software ER Mapper 7.0 dan hasil olahan citra kemudian di tampilkan 
dalam bentuk peta menggunakan software ArcGIS 10.3. Setelah mendapatkan peta sebaran suhu permukaan laut hasil olahan citra, hasil tersebut digunakan untuk menentukan titik lokasi sampling pengambilan sampel fitoplankton.

Metode yang digunakan dalam penelitian ini adalah metode deskriptif eksploratif yang bertujuan untuk mengetahui gambaran suatu objek pengamatan dan dapat menjelaskan perkembangan yang terjadi pada kondisi pengamatan, sedangkan metode yang digunakan untuk pengambilan data lapangan adalah metode purposive sampling yaitu pengambilan sampel dengan maksud dan tujuan tertentu dalam penelitian (Suryabrata, 1992), pengambilan sampel pada penelitian ini didasarkan dengan mempertimbangkan jarak stasiun dari titik outfall PLTU dan berdasarkan nilai suhu permukaan laut hasil olahan citra Landsat-8. Metode deskriptif digunakan untuk mendapatkan gambaran mengenai kenaikan suhu permukaan laut di perairan Tambak Lorok Semarang yang diakibatkan dari masuknya air bahang PT. Indonesia Power melalui pengukuran secara in situ di lapangan serta pengambilan sampel fitoplankton. Data yang didapat dideskripsikan dalam bentuk tabel dan grafik sehingga dapat diketahui apakah kenaikan suhu permukaan laut mempengaruhi kelimpahan fitoplankton pada perairan Tambak Lorok Semarang.

Pengambilan sampel fitoplankton dilakukan pada tanggal 7 Oktober 2019 pada pukul 08.00 14.00 WIB dan dilakukan 3 kali pengulangan pada tiap stasiunnya. Pengambilan sampel dilakukan dengan menggunakan plankton net yang memiliki diameter $25 \mathrm{~cm}$ dan mesh size 47 mikron. Sampel fitoplankton diambil dengan menyaring air secara aktif dengan cara ditarik menggunakan kapal dengan kecepatan $1-2$ knot selama 5 menit pada setiap stasiun. air yang telah tersaring kemudian dimasukkan ke dalam botol sampel berukuran $250 \mathrm{ml}$ dan ditambahkan formalin $4 \%$ sebagai pengawet sampel (Mayani et al., 2014). Pengambilan data suhu permukaan laut secara in situ pada perairan Tambak Lorok Semarang diambil pada 3 stasiun yang dibagi berdasarkan jarak stasiun dari titik outfall dan nilai suhu permukaan laut berdasarkan olahan citra Landsat - 8. Pengamatan fitoplankton dilakukan di Laboratorium Biologi Gedung E FPIK Universitas Diponegoro dengan menggunakan sedwick rafter yang memiliki panjang $50 \mathrm{~mm}$, lebar $20 \mathrm{~mm}$ dan tinggi $1 \mathrm{~mm}$ sehingga volume sedwick rafter adalah $1000 \mathrm{~mm} 3$ atau $1 \mathrm{ml}$. Pengamatan fitoplankton dilakukan dengan perbesaran 10x10 pada mikroskop. Identifikasi fitoplankton dilakukan dengan cara mencocokan gambar berdasarkan buku indentifikasi Yamaji (1979) dan kelimpahan fitoplankton dihitung berdasarkan rumus Welch (1952)

\section{HASIL DAN PEMBAHASAN}

Berdasarkan hasil pengolahan citra yang tersaji pada Gambar 1, wilayah penelitian dibagi menjadi 3 stasiun. Stasiun 1 merupakan stasiun yang memiliki nilai suhu permukaan laut sebesar $32{ }^{\circ} \mathrm{C}-34^{\circ} \mathrm{C}$ dan memiliki jarak $300 \mathrm{~m}$ dari titik outfall PLTU PT. Indonesia Power, stasiun 2 merupakan stasiun yang memiliki nilai suhu permukaan laut sebesar $30^{\circ} \mathrm{C}-32^{\circ} \mathrm{C}$ dan memiliki jarak $1 \mathrm{~km}$ dari titik outfall sedangkan stasiun 3 merupakan stasiun yang memiliki nilai suhu permukaan laut sebesar $28^{\circ} \mathrm{C}-30^{\circ} \mathrm{C}$ merupakan stasiun dengan lokasi yang paling jauh dari titik outfall dengan jarak 1,3 km. Komposisi fitoplankton yang ditemukan terdiri dari 14 genus fitoplankton yang termasuk dalam 3 kelas yaitu Bacillariophyceae (terdapat 11 genus yaitu Rhizosolenia, Pleurosigma, Coscinodiscus, Nitzchia, Chaetoceros, Lauderia, Thalassiothrix, Melosira, Stephanopyxis, Hemiaulus dan Isthmia), Dinophyceae (terdapat 2 genus yaitu Ceratium dan Peridinium) dan Cyanophyceae (terdapat 1 genus yaitu Spirulina). Komposisi fitoplankton terbanyak ditemukan pada stasiun 3 yang merupakan stasiun dengan jarak yang paling jauh dari lokasi outfall PLTU yaitu sebanyak 13 genus (Tabel 1). Bacillariophyceae merupakan kelas fitoplankton yang paling banyak di temukan, diikuti dengan kelas Dinophycea, pada kelas ini ditemukan dua genus yaitu Ceratium dan Peridinium pada semua stasiun. Kelas Cyanophyceae merupakan kelas dengan keberadaan yang paling sedikit, dimana hanya ditemukan 1 genus yaitu Spirulina pada stasiun 3. Bacillariophyceae merupakan kelas fitoplankton dengan komposisi yang paling banyak, hal ini dikarenakan kelas Bacillariophyceae lebih mampu menyesuaikan diri atau lebih mudah mengadaptasi diri dengan kondisi lingkungan disekitarnya dibandingkan dengan kelas fitoplankton lainnya, sedangkan menurut Arinardi et al. (1997), kelas Dinophyceae memiliki perkembangbiakan yang lebih lambat dibandingkan dengan kelas Bacillariophyceae. Menurut Cokrowati et al (2014), 
Dinophyceae adalah kelas fitoplankton terbesar kedua setelah Bacillariophyceae yang sering ditemukan di perairan laut. Berdasarkan hasil kelimpahan fitoplankton secara keseluruhan di Perairan Tambak Lorok, kelimpahan tertinggi terdapat pada stasiun 3 dengan jumlah sebesar 4035,7 Ind/L sedangkan pada stasiun 2 dengan jumlah sebesar 2812,7 Ind/L dan kelimpahan terendah terdapat pada stasiun 1 dengan jumlah sebesar 1494,7 Ind/L. Berdasarkan pengambilan nilai suhu permukaan laut secara in situ pada Perairan Tambak Lorok yang tersaji pada Gambar 2, dapat terlihat bahwa terjadi kenaikan suhu sebesar $5^{\circ} \mathrm{C}$ dengan nilai suhu mencapai $36,2^{\circ} \mathrm{C}$ pada stasiun 1 yang memiliki jarak $300 \mathrm{~m}$ dari titik outfall, suhu kemudian mengalami penurunan sebesar $3^{\circ} \mathrm{C}$ dengan nilai suhu sebesar $33,7^{\circ} \mathrm{C}$ pada stasiun 2 , dan terjadi penurunan pada stasiun 3 hingga nilai suhu sebesar $32,8^{\circ} \mathrm{C}$ dimana suhu sudah mendekati nilai normal suhu perairan sebesar $31^{\circ} \mathrm{C}$ menurut Nontji (1987). Perbandingan jumlah kelimpahan fitoplankton tiap kelas dan tiap stasiun secara lengkap tersaji dalam Tabel 2 dan grafik fitoplankton di Perairan Tambak Lorok tersaji pada Gambar 3.
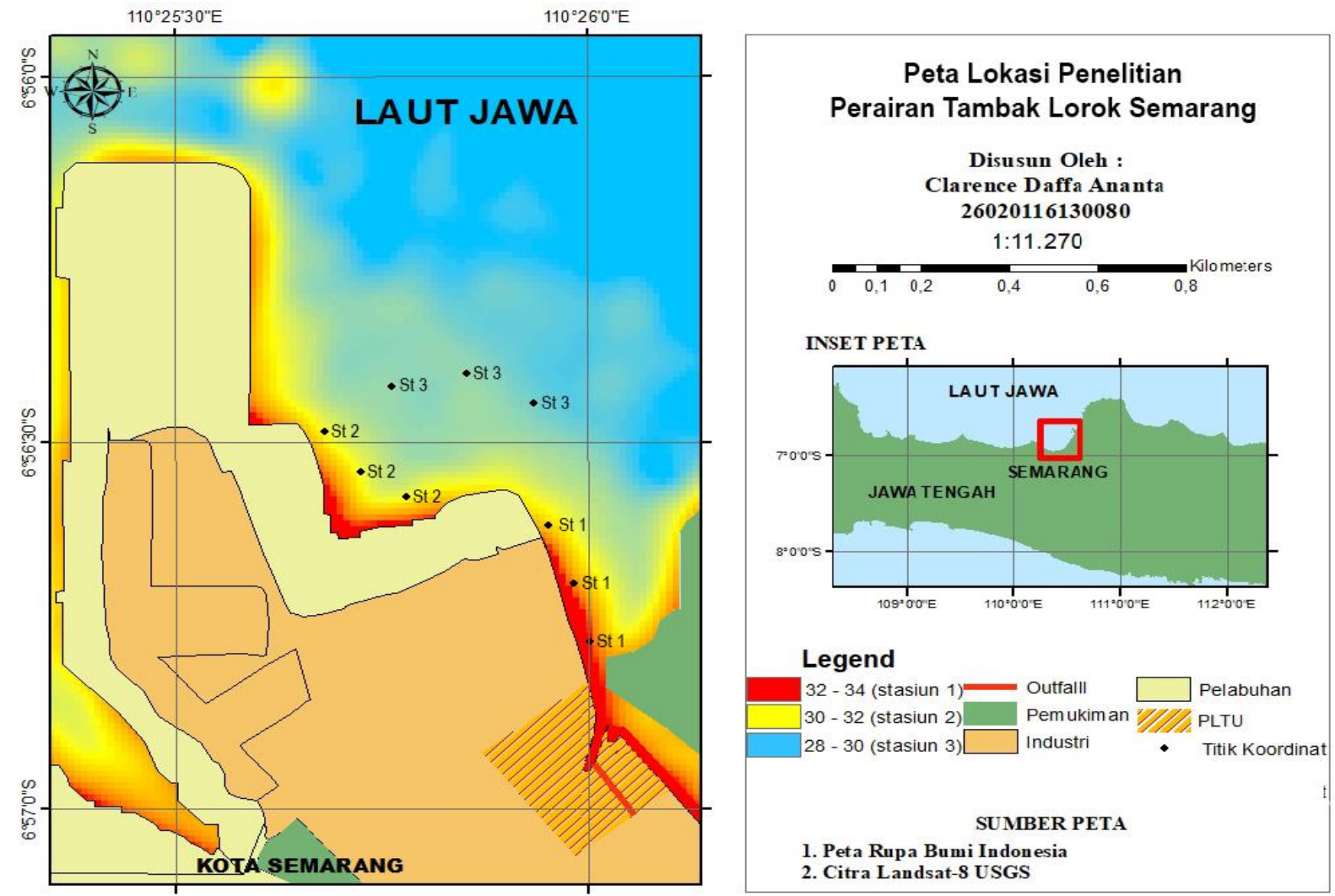

Gambar 1. Pola Sebaran Suhu di dan Stasiun Pengambilan Data

Kondisi Perairan Tambak Lorok yang merupakan lokasi tempat pembuangan air bahang PT. Indonesia Power Semarang memiliki dampak terhadap organisme fitoplankton, menurut Arisyana dan Yuliana (2012), fitoplankton merupakan organisme yang hidupnya melayang di perairan, dengan terjadinya kenaikan suhu permukaan laut yang disebabkan dari masuknya limbah air bahang, dapat mempengaruhi kelimpahan fitoplankton pada perairan tersebut. Kelimpahan fitoplankton mengalami kenaikan dari stasiun 1 hingga ke stasiun 3, dimana pada stasiun 1 nilai kelimpahan hanya sebesar $1494 \mathrm{Ind} / \mathrm{L}$, pada stasiun 2 sebesar 2812,7 Ind/L dan pada stasiun 3 sebesar 4035,7 Ind/L yang merupakan nilai tertinggi (Gambar 3). Pada stasiun 1 yang merupakan stasiun dengan nilai suhu tertinggi dan terjadi kenaikan suhu sebesar $5^{\circ} \mathrm{C}$ dengan nilai suhu sebesar $36,2^{\circ} \mathrm{C}$, kelimpahan fitoplankton menghasilkan nilai yang paling rendah dibandingkan dengan stasiun 2 dan stasiun 3. Pada stasiun 2, nilai suhu sudah mengalami penurunan sebesar $3^{\circ} \mathrm{C}$ dan stasiun 2 memiliki jarak yang lebih jauh dari titik outfall jika dibandingkan dengan stasiun 1, sedangkan nilai kelimpahan tertinggi terdapat pada stasiun 3, hal ini dikarenakan stasiun 3 memiliki 
jarak sejauh 1,3 km dari titik outfall dan merupakan stasiun dengan jarak yang paling jauh. Nilai suhu pada stasiun 3 juga sudah mengalami penurunan sebesar $4^{\circ} \mathrm{C}$ dengan nilai suhu sebesar $32,8^{\circ} \mathrm{C}$. Menurut Effendi (2003), kisaran suhu optimum bagi pertumbuhan fitoplankton sebesar $20-30^{\circ} \mathrm{C}$, hal ini menunjukkan bahwa sebaran air bahang pada Perairan Tambak Lorok Semarang mempengaruhi kenaikan suhu pada perairan tersebut sehingga mengalami kenaikan sebesar $5^{\circ} \mathrm{C}$ dan menjadikan wilayah perairan Tambak Lorok menjadi kurang optimum bagi pertumbuhan fitoplankton. Fitoplankton merupakan salah satu biota yang sensitif akan perubahan karakteristik perairan, karena sensifitasnya, fitoplankton sering dijadikan indikator terhadap kondisi ekologis suatu perairan (Lathifah et al., 2017). Komposisi dan kelimpahan fitoplankton akan berubah pada berbagai tingkatan sebagai bentuk respon terhadap perubahan - perubahan kondisi lingkungan baik secara fisik, kimia dan biologi. Perubahan dari kondisi lingkungan akan menjadi faktor yang mempengaruhi struktur komunitas dari fitoplankton, khususnya ketersediaan unsur hara atau nutrient dan kualitas cahaya serta kemampuan fitoplankton untuk memanfaatkannya (Nastiti \& Hartati, 2013). Tinggi rendahnya konsentrasi klorofil sangat terkait dengan kondisi oseanografis suatu perairan, dengan terjadinya kenaikan suhu permukaan laut, akan menyebabkan terhambatnya pertumbuhan dan mengurangi persebaran fitoplankton pada perairan, sehingga akan menyebabkan konsentrasi dan sebaran klorofil perairan menjadi rendah. Rendahnya konsentrasi dan sebaran klorofil akan menganggu proses fotosintesa pada perairan tersebut (Panjaitan, 2017).

Tabel 1. Komposisi fitoplakton yang ditemukan di Perairan Tambak Lorok, Semarang

\begin{tabular}{llccc}
\hline No & \multicolumn{1}{c}{ Genus } & Stasiun 1 & Stasiun 2 & Stasiun 3 \\
\hline Bacillariophyceae & & & + \\
1 & Rhizosolenia & + & + & + \\
2 & Pleurosigma & + & + & + \\
3 & Coscinodiscus & + & + & + \\
4 & Nitzchia & + & + & + \\
5 & Chaetoceros & + & + & + \\
6 & Lauderia & + & + & + \\
7 & Thalassiothrix & + & + & + \\
8 & Melosira & + & + & + \\
9 & Stephanopyxis & - & + & + \\
10 & Hemiaulus & - & & + \\
11 & Isthmia & + & + & + \\
Dinophyceae & & + & + \\
12 & Ceratium & + & - & + \\
13 & Peridinium & + & 12 & + \\
Cyanophyceae & & & + \\
14 & Spirulina & - & & + \\
\hline \multicolumn{7}{c}{ Jumlah jenis } & 11 & & + \\
\hline
\end{tabular}

Tabel 2. Kelimpahan fitoplakton (Ind/L) yang ditemukan di Perairan Tambak Lorok, Semarang

\begin{tabular}{lccc}
\hline \multicolumn{4}{c}{ Indeks Kelimpahan Ind/L } \\
\hline Kelas & Stasiun 1 & Stasiun 2 & Stasiun 3 \\
\hline Bacillariophyceae & $1073,46 \pm 210,3$ & $2608,92 \pm 411,5$ & $3614,44 \pm 470,6$ \\
Dinophyceae & $421,23 \pm 220,9$ & $203,82 \pm 9,61$ & $394,06 \pm 105,6$ \\
Cyanophyceae & 0,0 & 0 & 27,18 \\
\hline Jumlah & $1494,7 \pm 195,4$ & $2812,7 \pm 377,3$ & $4035,7 \pm 421,9$ \\
\hline
\end{tabular}




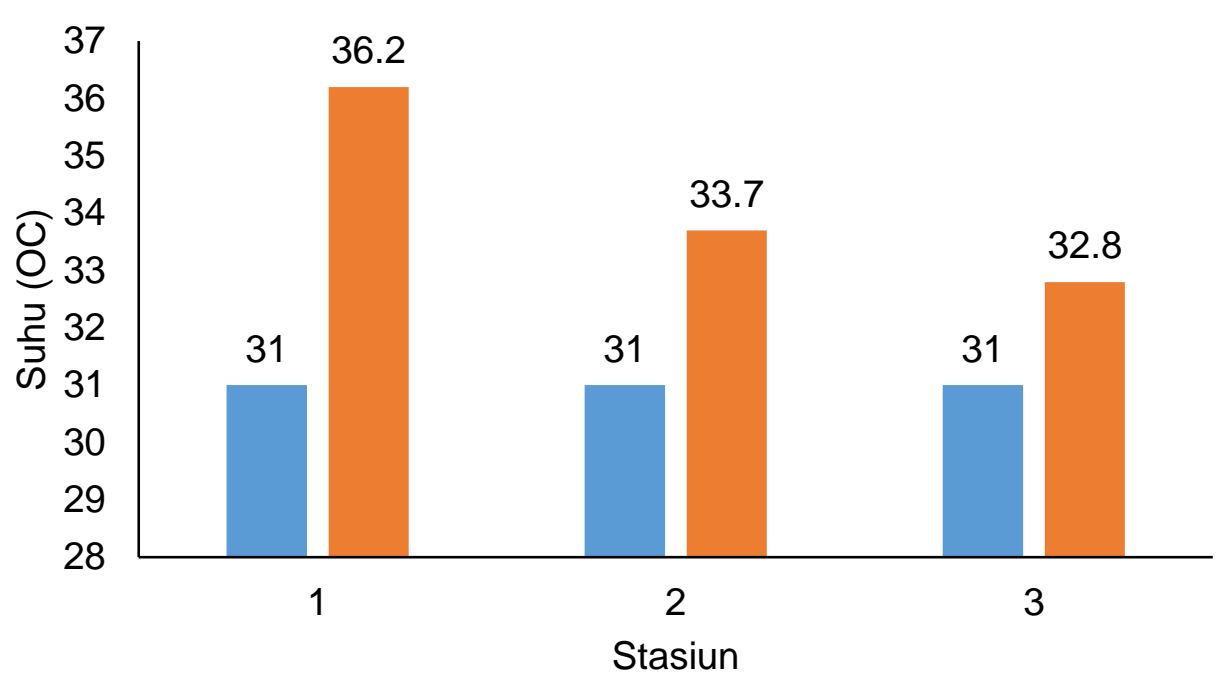

-Suhu Normal Perairan $\quad$ Kenaikan Suhu

Gambar 2. Grafik Kenaikan Suhu Permukaan Laut pada Tiap Stasiun

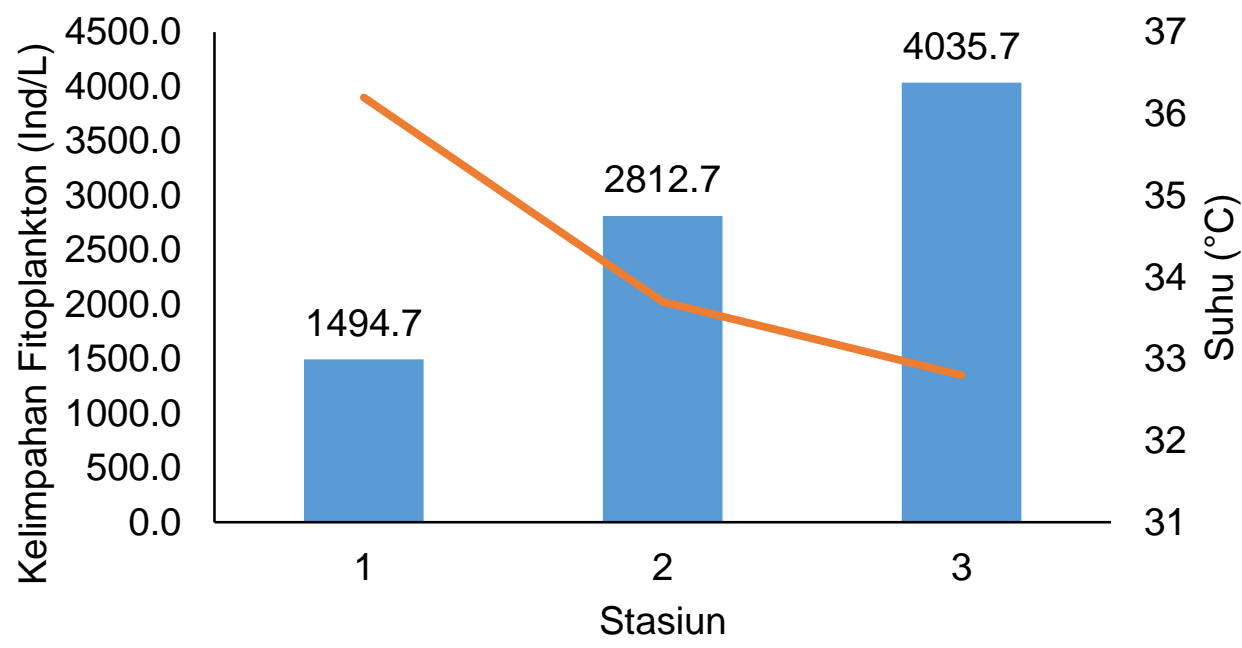

Kelimpahan Fitoplankton $\quad$ Suhu

Gambar 3. Grafik Kelimpahan Fitoplankton (Ind/L) di Perairan Tambak Lorok Semarang

Berdasarkan pada Tabel 2, dapat terlihat bahwa pada tiap stasiun, kelimpahan kelas Bacillariophyceae pada tiap stasiun memiliki nilai yang tertinggi. Pada stasiun 1 kelimpahan Bacillariophyceae sebesar 1073,46 sedangkan Dinophyceae sebesar 421,23. Pada stasiun 2 kelimpahan Bacillariophyceae sebesar 2608,92 sedangkan Dinophyceae sebesar 203,82. Pada stasiun 3 kelimpahan Bacillariophyceae sebesar 3614,44 sedangkan Dinophyceae sebesar 394,06 dan Cyanophyeae hanya sebesar 27,18 . Hal ini menunjukkan tingkat adaptasi yang tinggi yang dapat dilakukan oleh Bacillariophyceae pada kondisi ekstrim yang terjadi di perairan Tambak Lorok, dimana pada perairan tersebut memiliki suhu yang lebih tinggi dibandingkan dengan perairan normal lainnya. Menurut Arinardi et al. (1997), kelas Bacillariophyceae memiliki toleransi dan daya adaptasi yang tinggi, sehingga kelas Bacillariophyceae memiliki hasil kelimpahan yang tertinggi pada tiap stasiunnya dibandingkan dengan kelas Dinophyceae dan Cyanophyceae.

Kelimpahan yang dihasilkan pada kelas Cyanophyceae hanya sebesar 27,18 Ind/L dan hanya ditemukan pada stasiun 3 , yang merupakan stasiun dengan jarak paling jauh dari titik outfall dan sudah mengalami penurunan nilai suhu sebesar $4^{\circ} \mathrm{C}$, dapat disimpulkan bahwa tingkat adaptasi 
pada kelas Cyanophyceae jauh lebih rendah dibandingkan dengan tingkat adaptasi pada kelas Bacillariophyceae. Berdasarkan pada Gambar 3, dapat terlihat pengaruh kenaikan suhu permukaan laut terhadap kelimpahan fitoplankton di perairan Tambak Lorok. Dapat disimpulkan bahwa terdapat pengaruh kenaikan suhu permukaan laut terhadap kelimpahan fitoplankton, dimana dengan semakin tinggi suhu permukaan laut, nilai kelimpahan fitoplankton yang dihasilkan semakin rendah. Jika dibandingkan dengan penelitian yang dilakukan oleh Suryanti et al (2013) di Sungai Seketak Semarang yang menghasilkan nilai indeks kelimpahan fitoplankton berkisar antara 6.087 - 10.638 Ind/L, dapat disimpukan bahwa nilai indeks kelimpahan fitoplankton dengan pada perairan normal yang tidak terdampak air bahang lebih tinggi dibandingkan dengan perairan yang terdampak air bahang, sedangkan pada penelitian serupa yang dilakukan oleh Indraswari et al (2015) pada perairan Probolinggo yang terdampak air bahang PLTU Paiton menghasilkan nilai indeks kelimpahan sebesar $7.819 \mathrm{Ind} / \mathrm{L}$ dapat disimpulkan bahwa nilai indeks kelimpahan pada perairan tersebut mendekati dengan nilai indeks kelimpahan pada perairan Tambak Lorok yang juga terdampak air bahang PLTU.

\section{KESIMPULAN}

Ditemukan 14 genus fitoplankton pada Perairan Tambak Lorok Semarang dengan nilai kelimpahan berkisar 1494,7-4035,7 Ind/L, kenaikan suhu permukaan laut mempengaruhi kelimpahan fitoplankton pada perairan Tambak Lorok Semarang, pada stasiun 1 dimana terdapat kenaikan suhu sebesar $5^{\circ} \mathrm{C}$ dengan nilai suhu mencapai $36,2^{\circ} \mathrm{C}$, nilai kelimpahan yang dihasilkan hanya sebesar 1494,7 Ind/L, kemudian mengalami kenaikan pada stasiun 2 sebesar 2812,7 Ind/L dan pada Stasiun 3 sebesar 4035 Ind/L seiring dengan menurunnya nilai suhu pada Stasiun 2 dan Stasiun 3.

\section{DAFTAR PUSTAKA}

Arinardi O.H, Sutomo A.B., Yusuf S.A, Trimaningsih, Asnaryanti, E. \& Riyono, S.H., 1997. Kisaran Kelimpahan dan Komposisi Plankton Predominan di Perairan Kawasan Timur Indonesia. Pusat Penelitian dan Pengembangan Oseanologi-LIPI. Jakarta.

Arisyana \& Yuliana, 2012. Produktivitas Perairan. Bumi Aksara, Jakarta. 278 hlm.

Aryawati, R. \& Thoha, H., 2011. Hubungan Kandungan Klorofil-a dan Kelimpahan Fitoplankton di Perairan Berau Kalimantan Timur. Maspari Journal, 2(1):89 - 94.

Cokrowati, N., Sadikin, A., Zaenal, A., Bagus, D.H.S. \& Ayu, A.D., 2014. Kelimpahan dan komposisi fitoplankton di Perairan Teluk Kodek Pemenang Lombok Utara. Jurnal Ilmu Perairan, Pesisir, dan Perikanan, 3(1):21-26. Doi : 10.13170/depik.3.1.1279.

Effendi, H. 2003. Telaah Kualitas Air Bagi Pengelolaan Sumberdaya Dan Lingkungan Perairan. Kanisius, Yogyakarta.

Indraswari, B., Aunurohim \& Farid, K.M., 2015. Struktur Komunitas Fitolankton di Perairan yang Terdampak Air Bahang PLTU Paiton Kabupaten Probolinggo Jawa Timur. Jurnal Sains dan Seni ITS. 4(2):2337-3520.

Lathifah, N., Hidayat, J.W. \& Muhammad, F. 2017. Struktur Komunitas Fitoplankton Sebagai Dasar Pengelolaan Kualitas Perairan Pantai Mangrove di Tapak Tugurejo Semarang. Bioma, 19(2):164-169. Doi : 10.14710/bioma.19.2.164-169.

Mayani, P.S., Widianingsih, W. \& Endrawati, H., 2014. Kajian Struktur Komunitas Fitoplankton Di Perairan Pantai Desa Tapak Kecamatan Tugu Kota Semarang. Journal of Marine Research. 3(4):535-543. Doi : 10.14710/jmr.v3i4.11412.

Nastiti, A.S. \& Hartati, S.T. 2013. Struktur Komunitas Plankton dan Kondisi Lingkungan Perairan Di Teluk Jakarta. Bawal: Widya Riset Perikanan Tangkap. 5(3):131-150. Doi: 10.15578/bawal.5.3.2013.131-150. 
Nontji, A. 1987. Laut Nusantara. Djambatan, Jakarta.

Panjaitan, R.R. 2017. Analisis Sebaran Suhu Permukaan Laut dan Konsentrasi Klorofil - A di Perairan Belawan Kota Medan Provinsi Sumatera Utara. Jurnal Fakultas Perikanan dan Kelautan Universitas Riau.

Sitinjak, D.F., Suryo, A.A.D \& Helmi, M., 2017. Sebaran Suhu Permukaan laut Akibat Air Bahang Berdasarkan Citra Satelit Landsat-8 di Perairan PLTU Labuhan Angin Sibolga Sumatera Utara. Jurnal Oseanografi, 6(1):124-130.

Subardjo, P. \& Ario, R., 2015. Penyebaran Limbah Air Panas PLTU di Kolam Pelabuhan Semarang. Jurnal Kelautan Tropis. 18(3):178-183. Doi : 10.14710/jkt.v18i3.531

Subardjo, P., Ario, R. \& Handayo, G., 2016. Pola Persebaran Limbah Panas PLTU di Kolam Pelabuhan Tambak Lorok Semarang. Jurnal Kelautan Tropis. 19(1):48-54. Doi: 10.14710/ jkt.v19i1.600.

Suryabrata, S., 1992. Metoda Penelitian. Rajawali Press, Jakarta. 13 hlm.

Suryanti, Siti, S. \& Susi S., 2013. Kualitas Perairan Sungai Seketak Semarang berdasarkan Komposisi dan Kelimpahan Fitoplankton. Journal of Management of Aquatic Resources. 2(2):38-45.

Welch., 1952. Limnology. Graw Hill Book Company, New York.

Wibowo, M. \& Asvaliantina, V. 2018. Kajian Dispersi Panas Akibat Air Limbah Rencana Pembangunan PLTU Kuala Tungkai Provinsi Jambi. Jurnal Teknologi Lingkungan, 19(1):1-12. Doi : 10.29122/jtl.v19i1.1736.

Wijaya, Y.J., Yusuf, M. \& Helmi, M., 2015. Studi Variabilitas Spasial dan Temporal Temperatur Permukaan Laut berdasarkan Analisis Citra Termal Satelit LANDSAT - 8 di Perairan PLTU Sumuradem Indramayu Jawa Barat. Jurnal Oseanografi, 4(1):141-149.

Yuliana. 2015. Distribusi dan Struktur Komunitas Fitoplankton di Perairan Jailolo Halmahera Barat. Jurnal Akuatika. 6(1):41-48. 